\title{
The Effect of Green Purchase Intention Factors on The Environmental Friendly Detergent Product (Lerak)
}

\author{
Nia Budi Puspitasari ${ }^{1}$, Dyah Ika Rinawati ${ }^{2}$, Hery Suliantoro ${ }^{3}$ and Bayu Dwi Sutrisno ${ }^{4}$ \\ 1,2,3,4 Department of Industrial Engineering, Faculty of Engineering, Diponegoro University, Semarang - Indonesia
}

\begin{abstract}
Preference of influence of green purchase intention factor to environmentally friendly detergent product (lerak). Awareness of the current world community of the importance of environmental sustainability is increasing, this behaviour can be seen from the consumption patterns of people who start wanting environmentally friendly products. This condition makes many manufacturers adapt environmental problems in each of its products. Products that adapt to green product environmental issues can pave the way for manufacturers to enter eco-friendly markets as well as environmentally friendly detergents lerak. In this study using survey methods to determine the extent of influence of each factor to the intention of purchasing to environmentally friendly product. Factors studied are environmental concern, social influence, self-image, environmental knowledge, and perceived product price and quality against green purchase intention. From the results of this study found that all these factors have a significant influence on the green purchase intention of environmentally friendly detergent, but the most influential factor is the environmental knowledge which is the most important dimension and has the most significant influence on the intention of purchasing environmentally friendly detergent.
\end{abstract}

Keywords: Green purchase intention, lerak, environmentally friendly products.

\section{Introduction}

World public awareness of the importance of environmental sustainability is on the rise, the occurrence of environmental disasters, environmental destruction of global warming and climate change is causing the increasing public awareness of the surrounding environment, this also affects the habits of society as consumers who begin to tend to want products that are environmentally friendly. This behavior can be seen from the attitude of consumer awareness of the environmental sustainability in the surrounding which is increasingly likely to prefer an environmentally friendly product. Along with the emergence of a green consumer community that wants environmentally friendly products with minimal damage to the environment, many industries are beginning to adapt to environmental problems in every activity, from considering each raw material and the resulting environmental impact. According to [1] the green consumer is the nature of consumers who want to always buy environmentally friendly products and actively care and follow environmental issues. The emergence of green consumer is calling every producer to adapt environmental problems in each of its products, it can be seen with the enthusiasm of APEC countries to register environmentally friendly products (Ministry of Trade of the Republic of Indonesia, 2009-2015).

Green purchasing intention is the possibility and willingness of a consumer who is interested in environmentally friendly and conscious issues to choose a more environmentally friendly product compared to conventional products now in the production process tends to override the impact and influence on the environment [2]. The emergence of green purchase intention is also influenced by awareness to return to nature (back to nature), in this case the use of detergent lerak for some

*Corresponding author: niabudipuspitasari@gmail.com 
batik producers and the community is an indication that shows the awareness of the parties who often dabbled in the development of the industrial world, especially companies producing detergent. In the manufacture of detergents there are several uses of hazardous and environmentally damaging chemicals such as surfactants, NTAs, EDTA (Ethylene Diamine Tetra Acetate), STPP (Sodium Tri Poly Phosphate), ABS (Alkyl Benzene) which can have an adverse impact on the environment. STTP or phosphate also has no toxicity, but may cause enrichment of excessive eutrophication nutrients so that uncontrolled algae growth can result in the extinction of the living biota in the water. Eutrophication is a process whereby plants grow faster than normal growth (blooming) in other words water pollution is caused by the emergence of other nutrients such as excessive phosphate into the ecosystem [3]. In addition to the hard biodegradable environment, these ingredients also have adverse effects on the skin such as bruises, rough skin, cracked, and even can progress into an infection. A real example is what happens to Rawa Lake Pening adverse effects of phosphate waste can result in uncontrolled algae growth and reduced fish populations in the lake [4]. Economically, Rawa Pening Lake has a very high role for irrigation, agriculture, fishery, hydro power, and tourism. The land use in this area is $35 \%$, rice field $13,3 \%$, shrub / open land $166 \%$, settlement $13.8 \%$, plantation $8 \%$, mixed garden $7.8 \%$, swamp / lake $4.5 \%$, and other use $1 \%$ [5].

While environmental issues campaigned around the world have changed the thinking of most of the world's mindset to go back to nature and switch to environmentally friendly products and become one of the most important purchasing criteria for green consumers. This is different from what happens in Indonesia, in general, Indonesian people still show a tendency to use ordinary non-environmentally friendly detergent products instead of using detergents from lerak that are more environmentally friendly. This condition is in contrast to the phenomenon of green consumer is happening in the world. Therefore, with this research, researchers want to increase public interest to detergent lerak in order to maintain environmental sustainability.

\section{Literature review}

\subsection{Lerak}

Sapindus Rarak De Candole is another name of the lerak fruit known in Java as clerk or also called rerek is a plant known for its use of seeds that are often used in traditional detergents. Lerak is included in the Spermatophyta division, which grows in Java and Sumatera with altitude 450-1500m above sea level, plant height can reach $15-42 \mathrm{~cm}$ and dull white stems are round and hard can reach up to $1 \mathrm{~m}$. While the seeds are round, hard, diameter $\pm 1.5 \mathrm{~cm}$ and brownish yellow. Inside the fruit there is a flesh of a fragrant aroma. This lerak plant begins to bear fruit at the age of 5-15 years, generally fruitful season at the beginning of the rainy season and produce seeds of 1000-1500 seeds. Based on the results of research published in several journals mentioned that fruit, bark, seeds, and leaves of lerak plants contain saponins, alkaloids, steroids, antikuinons, polyphenols, and tannins.

\subsection{Green Purchase Intention}

Green Purchase Intention is defined as the possibility and desire of a consumer who is interested in environmental and conscious issues to choose a more environmentally friendly product compared to conventional products now that most of the production process tends to override the impact of environmental impacts [2].

\subsection{Green Product}

According to [6] green products are products that are harmless to humans and the environment, are not wasteful of resources, do not produce excessive waste, and do not involve animal cruelty. Green product must consider the environmental aspects of the product life cycle so as to minimize negative impacts on nature. Such minimization efforts to encourage all parties to play a role in technology development towards environmentally friendly products. In the production sector, various ways can be done to produce a product that is environmentally friendly one of them by using the concept of sustainable green product.

In essence, green product is an effort to minimize waste when the production process in addition to maximize the product made as well as meet environmentally friendly requirements. Green product it must have a durable quality product in the sense of not easily damaged, does not contain toxins, made from materials that can be recycled and has a minimalist packaging. The quality of the product as above still uses energy or emission-generating resources during the manufacturing process, so the green product is where a product has the smallest possible impact on its impact on the environment. Things to watch out for from the product are about price, quality, convenience, and availability of the product. Consumers will pay more for green products. A more expensive price than a specified average price can only be sold by adding value to the product. Many people think that the effectiveness of green product will decrease from ordinary products. The assurance of product quality is fundamental and should be communicated convincingly. Quality is judged from several features including performance, appearance, feeling, comfort, and robustness of a product.

A very important concept in a green product is to minimize consumer disappointment so that consumers try and buy green products. Consumers usually feel that many attributes make a product better. A good strategy offers environmental proofing in several categories at the same time, such as water pollution, waste, and even less satisfactory quality. Believing in quality is indispensable and should be communicated in a convincing way. 


\section{RESEARCH METHODOLOGY}

\subsection{Conceptual Model}

Conceptual model can be interpreted as picture dimension or variable used by consumer for consideration in choosing and buying a product. In conceptual model research must be clear independent variable (independent) and dependent variable (dependent). The following are the green purchase intention variables used in this study:

a. Green Purchase Intention: The possibility and willingness of a person to prefer eco-friendly products over traditional products in consumer purchase decisions [7].

b. Environmental Concern: An attitude that reflects the care of environmental destruction and the lack of public concern for environmental conservation [7].

c. Social Influence: Is part of the social context among adolescents or young adults [8].

d. Self-Image: Self-image as someone who is seen Ecofriendly in the eyes of others [9]

e. Environmental Knowledge: Community knowledge of the environment, aspects of the environment and its impact on sustainable development. [10].

f. Perceived Product Price and Quality: Public perception considers environmentally friendly products to be of lower quality at higher prices [11].

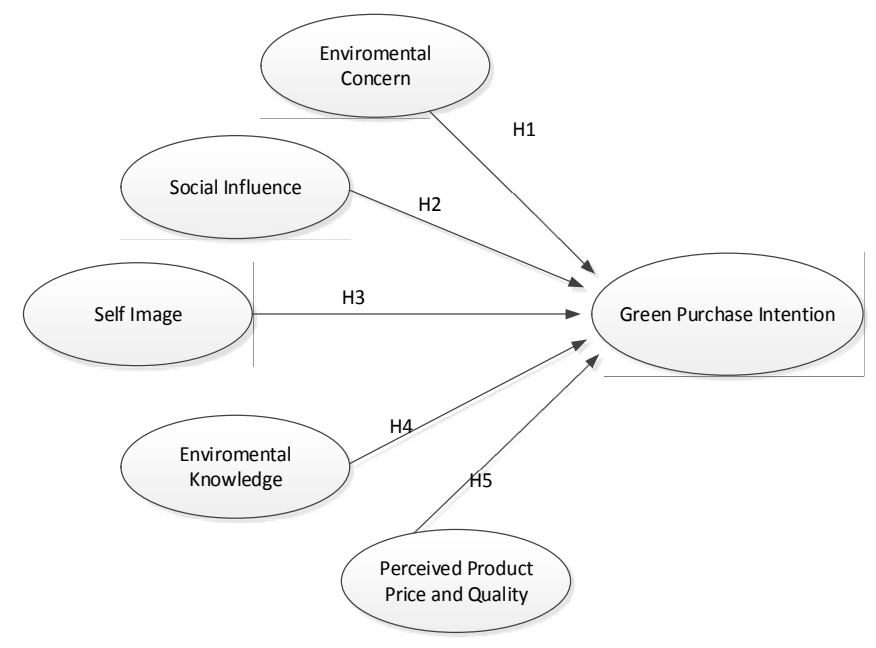

Fig. 1. Conceptual Model

\subsection{Variable Indicators}

Based on the variables used in this study, obtained indicators used as a tool for consumer assessment as listed in table 2.

Table 1. Green Purchase Intention Variable Indicator

\begin{tabular}{|l|l|}
\hline Code & \multicolumn{1}{|c|}{ Variable Indicator } \\
\hline G1 & $\begin{array}{l}\text { I intend to buy eco-friendly products because it } \\
\text { reduces pollution. }\end{array}$ \\
\hline
\end{tabular}

\begin{tabular}{|c|c|}
\hline G2 & $\begin{array}{l}\text { I intend to switch to another brand for } \\
\text { ecological reasons. }\end{array}$ \\
\hline G3 & $\begin{array}{l}\text { When going to buy a product, I look at the raw } \\
\text { material label to see if it contains things that are } \\
\text { damaging to the environment. }\end{array}$ \\
\hline G4 & $\begin{array}{l}\text { When I have two choices for the same product } \\
\text { I prefer an environmentally friendly product, } \\
\text { especially when the quality of the product is the } \\
\text { same. }\end{array}$ \\
\hline G5 & $\begin{array}{l}\text { I will talk about others if I do not support } \\
\text { environmental protection. }\end{array}$ \\
\hline E1 & $\begin{array}{l}\text { I am worried about the deterioration of } \\
\text { Indonesia's environmental quality }\end{array}$ \\
\hline $\mathrm{E} 2$ & $\begin{array}{l}\text { The Indonesian environment is my main } \\
\text { concern. }\end{array}$ \\
\hline E3 & $\begin{array}{l}\text { Indirectly, I am involved in environmental } \\
\text { protection issues in Indonesia. }\end{array}$ \\
\hline $\mathrm{E} 4$ & $\begin{array}{l}\text { I often think about how the quality of the } \\
\text { Indonesian environment can be improved. }\end{array}$ \\
\hline $\mathrm{S} 1$ & $\begin{array}{l}\text { I learned a lot about environmentally friendly } \\
\text { products from my friends. }\end{array}$ \\
\hline $\mathrm{S} 2$ & $\begin{array}{l}\text { I learned about environmental issues from my } \\
\text { friends. }\end{array}$ \\
\hline S3 & $\begin{array}{l}\text { I always discuss with my friends about } \\
\text { environmentally friendly products }\end{array}$ \\
\hline $\mathrm{S} 4$ & $\begin{array}{l}\text { Me and my friends, discuss about what are the } \\
\text { environmental issues that are developing. }\end{array}$ \\
\hline S5 & $\begin{array}{l}\text { I always buy environmentally friendly products } \\
\text { with my friends. }\end{array}$ \\
\hline S6 & $\begin{array}{l}\text { I always share information about green } \\
\text { products with my friends. }\end{array}$ \\
\hline $\mathrm{T} 1$ & $\begin{array}{l}\text { By supporting environmental protection I find } \\
\text { it more socially attractive. }\end{array}$ \\
\hline $\mathrm{T} 2$ & $\begin{array}{l}\text { By supporting environmental protection I feel } \\
\text { more special. }\end{array}$ \\
\hline $\mathrm{T} 3$ & $\begin{array}{l}\text { I will talk about others if I do not support } \\
\text { environmental protection. }\end{array}$ \\
\hline $\mathrm{C} 1$ & $\begin{array}{l}\text { I know what ingredients are from } \\
\text { environmentally friendly detergents. }\end{array}$ \\
\hline $\mathrm{C} 2$ & $\begin{array}{l}\text { Using eco-friendly products I can reduce } \\
\text { environmental pollution. }\end{array}$ \\
\hline $\mathrm{C} 3$ & $\begin{array}{l}\text { I know information about green products that } \\
\text { are growing. }\end{array}$ \\
\hline $\mathrm{C} 4$ & $\begin{array}{l}\text { I know information about eco-friendly } \\
\text { products. }\end{array}$ \\
\hline P1 & $\begin{array}{l}\text { I prefer eco-friendly products, even if the price } \\
\text { of the product is more expensive. }\end{array}$ \\
\hline $\mathrm{P} 2$ & $\begin{array}{l}\text { I prefer eco-friendly products, even if product } \\
\text { quality is lower. }\end{array}$ \\
\hline
\end{tabular}

\subsection{Method of Collecting Data}

The survey was conducted on 144 respondents through questionnaires consisting of identity questions such as name, age, gender, and income and 24 research questions. The research question put forward to use Likert scale with 5 scale 
points is strongly disagree, disagree, neutral, agree, and strongly agree. Preparation of questionnaires has been adjusted for the items of questions based on the variables studied.

\subsection{Data Processing Method}

This research uses a linear regression method, including test validity of descriptive statistical reliability test that will identify whether or not the influence of these factors in the decision of purchasing environmentally friendly detergent and strong relation between those variables by using a linearity test with the help of SPSS software.

\section{RESULTS AND DISCUSSION}

In this study, the general overview of respondents by sex, female respondents have 94 respondents, more than respondents of the male gender as much as 50 respondents from a total of 144 respondents. From the results of this questionnaire shows that the user of environmentally friendly detergent lerak more women because will consider most of the female respondents are housewives and batik craftsmen Semarang area that almost every day more often washing clothes or batik. Most of them have known the adverse effects of the compounds contained in ordinary detergents can be a deadly wastewater to the environment besides the usual detergent side effects are also less good can damage the skin even in the long term cause cancer to the skin for the user.

In data processing using Factor analysis, there is assumed that must be fulfilled before that data or sample assumed enough and there is a correlation between variables. Multiple linear regression analysis is used in this study with the aim to prove the hypothesis about the influence of independent variables partially or jointly to the dependent variable. Multiple linear regression analysis is used in this study with the aim to prove the hypothesis about the influence of independent variables partially or jointly to the dependent variable.

Table 2. Results of Linear Multiple Analysis

\begin{tabular}{|c|c|c|c|c|c|}
\hline \multirow[b]{2}{*}{ Model } & \multicolumn{2}{|c|}{$\begin{array}{l}\text { Unstandardized } \\
\text { Coefficients }\end{array}$} & \multirow{2}{*}{$\begin{array}{c}\text { Standardized } \\
\text { Coefficients } \\
\text { Beta } \\
\end{array}$} & \multirow[b]{2}{*}{$t$} & \multirow[b]{2}{*}{ Sig. } \\
\hline & $B$ & Std. Error & & & \\
\hline \begin{tabular}{l|l}
1 & (Constant)
\end{tabular} & 4,082 & 1,122 & & 3,639 &, 000 \\
\hline Environtment Concem & 252 & 066 & 280 & 3,802 &, 000 \\
\hline Social Influence &, 069 & , 034 & 136 & 2,039 &, 043 \\
\hline SelfImage & 253 & 091 & 168 & 2,779 & 006 \\
\hline Environtment Knowledge &, 333 & 066 &, 328 & 5,018 &, 000 \\
\hline Perceived Product and Quality & 264 & 0,088 & 173 & 3,010 &, 003 \\
\hline
\end{tabular}

The regression equation model that can be written from the results in regressive forms is as follows:
$\mathrm{Y}=4,082+0.252 \mathrm{X} 1+0.069 \mathrm{X} 2+0.253 \mathrm{X} 3+0.333 \mathrm{X} 4+$ $0.264 X 5$

The $\mathrm{T}$ test used to test the regression model for each variable. The following will explain the test each variable partially.

1. The test results obtained by value $t$ arithmetic for variable Environment Concern show the value of $\mathrm{t}$ arithmetic $=$ 3.802 with a significance value of $0.000<0.05$. Thus obtained that the hypothesis stating that Environment Concern has a significant influence on the decision to purchase green product is acceptable. According to [10]. Environment Concern is an attitude that reflects one's concern for the damage experienced by the surrounding environment and the lack of public attention to environmental conservation. According to the consumer's point of view that if consumers have environmental awareness, then the consumer's intention to buy environmentally friendly detergent products can increase. But by the results of the data show different things, this can be influenced by several factors, among others, is the availability of these products that cause a consumer intention to buy the product is reduced even though the consumer has an environmental awareness

2. The test results obtained $t$ value for Social Influence variable shows the value of $t$ arithmetic $=2.039$ with a significance value of $0.043<0.05$. Thus, it is obtained that the hypothesis which states that Social Influence has a significant influence on the decision to purchase green product is acceptable. These results indicate that there are many influences of peers, co-workers, families and the environment around the person. Where it contributes to the determination of consumer consumption behavior the greater the effect will increase the perception of a person to perform a positive action in the form of a decision to switch from ordinary detergent to buy environmentally friendly detergent products.

3. The test results obtained by value $t$ arithmetic for Self Image variables show the value of $t$ arithmetic $=2.779$ with a significance value of $0.006<0.05$. Thus obtained that the hypothesis that Self Image has a significant influence on the decision to purchase green products is acceptable. From the research results can be seen that the influence of self-image (self-image) has a positive and significant influence on the green purchase intention because the personality attached to a person can affect consumption patterns and the desire of the person to make purchases of environmentally friendly products. According to [9] self-image or self-image is the personality of someone who is seen in the eyes of others more environmentally friendly this result shows that the greater the effect of someone in the eyes of others will be able to determine purchasing decisions against the person. This can be influenced also by the extent of social interaction to the social environment and surrounding communities.

4. The test results obtained value $t$ arithmetic for variable Environment Knowledge shows $\mathrm{t}$ value $=5,018$ with a 
significance value of $0.000<0.05$. Thus obtained that the hypothesis that environment Knowledge has a significant influence on the decision to purchase green product is acceptable. According to [10], environmental knowledge is the community's knowledge of the environment, its environmental aspects and its very important impact of sustainable development. Due to the lack of understanding of the respondents and the surrounding community on the environment, if from the related producers want to increase the buying interest of the community towards the environmentally friendly detergent related producers can cooperate with the government to provide information or counseling related to the positive value of the use of environmentally friendly detergent lerak to nature and negative effects of detergent use usually in which there are harmful compounds. With the provision to the surrounding community about the understanding will result in a positive assessment of consumers and can increase the green purchase intention or desire to buy environmentally friendly detergent.

5. The test results obtained $t$ value arithmetic for variable Perceived Product and Quality shows $t$ value $=3.010$ with a significance value of $0.003<0.05$. Thus obtained that the hypothesis that Perceived Product and Quality have a significant influence on the decision to purchase green product is acceptable. According to [11], people's perception of eco-friendly products has higher prices, but lower quality than traditional products. So it can be concluded that the perception of quality and price of environmentally friendly detergent products has a positive and significant influence on green purchase intention. This result is shown by the high perception of respondents regarding the quality and price of environmentally friendly detergent products will be the basis of a big decision to buy products labeled green product. As the marketing concept that quality and price are factors that can influence purchasing decisions. Similarly, with environmentally friendly detergent products. The assumption that environmentally friendly detergent products are not expensive and have good quality will increase the purchasing decision of the environmentally friendly detergent products lerak.

\section{CONCLUSION}

The result of linear regression analysis shows that the green purchase intention variable dimension which has the highest importance for consumers in buying environmentally friendly detergent products is Environment Knowledge, Environment Concern and Perceived Product and Quality).

Of the three highest variables, the variable that has the greatest influence is the Environment Knowledge (Environmental Knowledge) variable with which it can be known that most affect the green purchase intention to the environmentally friendly detergent caused by the lack of public knowledge about environmentally friendly detergent products, especially detergent products lerak.
There are factors influencing people's buying interest in environmentally friendly detergents such as lack of community knowledge about environmental influences and ordinary deterrent effects on the environment. In addition, the lack of information on environmentally friendly products that are developing and its constituents make people ambivalent to choose and buy the product. This research was carried out in an effort to realize low carbon / low carbon community development in the development process

\section{REFERENCES}

1. Ščypa, P. Lingkungan Pemasaran dan Povedenie. Markets. Ekonomi dan Manajemen: Current Issues and Perspectives, 156-159 (2006)

2. Ali, A., \& Ahmad, I.. Enviroment Friendly Products : factors that influence the Green Purchase Intention of Pakisan Consumer. Pakistan Journal Engineering Technology Sciences, 2, 84-117 (2012)

3. Pemerintah Kabupaten Pati. Deterjen Ramah Lingkungan. PATI: Pemerintah Kabupaten Pati. Retrieved from https://patikab.go.id/v2/id/2015/11/14/deterjen-ramahlingkungan/ (2015)

4. Zulfia, Naila A. Status Trofik Perairan Rawa Pening Ditinjau dari Kandungan Unsur Hara(NO3 dan PO4) Serta Klorofil. BAWAL, 189-199 (2013)

5. P4N, U. Penyusunan Rencana pengelolaan Kawasan Rawapening Propinsi Jawa Tengah. Badan Perencanaan Pembangunan Daerah Propinsi Jawa Tengah. Yogyakarta: P4N UGM (Pusat Penelitian Perencanaan Pembangunan Nasional Universitas gadjah Mada) (2000)

6. Junaedi. Pengaruh Kesadaran Lingkungan pada Niat Beli ProdukHijau: Studi Perilaku Konsumen Berwawasan Lingkungan. Benefit Jurnal Manajemen dan Bisnis, 189201 (2005)

7. Abdul, A.G., \& Muhmin. Explaining Consumer's Willingers to be Enviroment Friendly Products International Journal of Consumer Studies Volime 31, 237 247 (2007)

8. Rehman, \& Dost. Conceptualizing Green Purchase Intention in Emerging. The 2013 WEI International Academic Conference Proceedings (pp. 100-120). Istanbul, Turkey: Hailey College of Commerce, Hailey College of Commerce University of the Punjab, Lahore, Pakistan. (2013)

9. Lee, Kaman. "Opportunities for green marketing: young consumers", Marketing Intelligence \& Planning, Vol. 26 Issue: 6, pp.573-586 (2008)

10. Mostafa, M. M. A Hierarchical Analysis of the Green Consciouness of the Egyptian Consumer. Psychology \& Marketing Vol. 24, 445-473 (2007)

11. D'Souza, C., Taghian, M., Lamb, P., \& Peretiatkos, R. Green products and corporate strategy: An empirical investigation. Society and Business Review,1, 144 - 157 (2006) 